Deni Sunaryo

\title{
Pengaruh Profitabilitas dan Struktur Aktiva terhadap Struktur Modal (Studi Kasus pada Perusahaan Sub Sektor Transportasi Di Bursa Efek Asia Tenggara Periode 2012-2018)
}

\author{
Deni Sunaryo \\ Universitas Serang Raya \\ * Email Koresponden :denisunaryomm@gmail.com
}

\begin{abstract}
Abstrak
Pembahasan mengarah kepada pengaruh Profitabilitas dan Struktur Aktiva terhadap Struktur Modal yang menunjukkan ketidaksamaan hasil pada penelitian terdahulu. Oleh sebab itu, penelitian ini bertujuan untuk mengetahui pengaruh Profitabilitas dan Struktur Aktiva terhadap Struktur Modal. Penelitian ini menggunakan study empiris untuk perusahaan sub sektor transportasi di Asia Tenggara tahun 2012-2018. Data yang digunakan dalam penelitian ini adalah data sekunder dari perusahaan transportasi yang terdaftar di bursa efek selama tahun 2012-2018. Metode pengambilan sampel diambil dan menghasilkan 8 perusahaan sebagai sampel. Analisis statistic yang digunakan dalam penelitian ini adalah metode regresi berganda, uji parsial dan uji simultan dengan SPSS versi 23. Hasil penelitian secara parsial menyimpulkan bahwa Profitabilitas berpengaruh secara negatif signifikan terhadap Struktur Modal dan Struktur Aktiva berpengaruh secara negatif signifikan terhadap Struktur Modal. Hasil penelitian secara simultan menunjukkan nilai $\mathrm{F}$ hitung lebih besar dari nilai $\mathrm{F}$ tabel yaitu 6,348 > 3,17, dan nilai signifikansinya yang lebih kecil dari pada 0,05 $(0,003<0,05)$. Sehingga, Profitabilitas dan Struktur Aktiva secara bersama-sama berpengaruh secara simultan terhadap Sturktur Modal. studi menyimpulkan bahwa semua variabel independen memiliki pengaruh terhadap struktur modal. Berdasarkan hasil uji koefisien determinasi, nilai adjust $\mathrm{R}$ Square adalah sebesar 19,3\%, sisanya80,7\% dipengaruhi oleh variabel lain diluar penelitian ini.
\end{abstract}

Kata kunci: profitabilitas, struktur aktiva dan struktur modal

\section{Pendahuluan}

Perkembangan teknologi transportasi membawa perubahan aktivitas manusia yang berakibat terhadap perubahan tata kehidupan. Transportasi udara berupa pesawat bukan lagi alat transportasi mahal. Setiap orang dapat naik pesawat karena cepat, nyaman dan harga terjangkau. Transportasi air berupa kapal tidak hanya sebagai alat transportasi tetapi juga sarana wisata. Transportasi darat semakin banyak memberikan alternatif perjalanan. Perkembangan transportasi membutuhkan ruang sebagai sarana dan prasarana. Semakin banyak alat transportasi di darat, laut dan udara maka pembangunan sarana dan prasarana penunjang semakin mendesak. Seperti perluasan jalan, terminal, bandara, dermaga atau pelabuhan. Pembangunan prasarana transportasi akan mengubah kondisi wilayah di suatu negara. Lahan-lahan produktif seperti hutan atau sawah diubah untuk membangun jaringan jalan. Di beberapa negara Association of Southeast Asian Nation (ASEAN), rekayasa jaringan lalu lintas transportasi darat sudah sangat canggih. Contoh Singapura dan Thailand yang mengembangkan transportasi darat bawah tanah. Perubahan penggunaan lahan sebagai sarana 


\section{Deni Sunaryo}

transportasi terjadi juga di sekitar bandara. Lahan yang sebelumnya digunakan sebagai pemukiman atau persawahan dikonversi demi perluasan area bandara. Contoh, pembangunan Bandara Suvarnabhumi di Thailand menggantikan Bandara Don Muang, Bandara Luang Prabang di Laos, Bandara Ninoy Aquino di Filipina, dan lain-lain. Sumber kompas.com

Selain itu, di negara Asia Tenggara perusahaan yang termasuk dalam sektor transortasi dalam kegiatan operasionalnya harus menggunakan peralatan dan teknologi yang nilai investaasinya tidak sedikit, dan semua peralatan tersebut digolongkan kedalam aset perusahaan. Struktur modal merupakan masalah yang penting bagi perusahaan karena baik buruknya struktur modal akan mempunyai efek langsung terhadap posisi finansial perusahaan, terutama dengan adanya utang yang sangat besar akan memberikan beban kepada perusahaan. Struktur modal yang optimal adalah struktur modal yang mengoptimalkan keseimbangan antara risiko dan pengembalian sehingga memaksimumkan harga saham. Untuk itu, dalam penetapan struktur modal suatu perusahaan perlu mempertimbangkan berbagai variabel yang memengaruhinya.

Tujuan manajemen struktur modal adalah memadukan sumber-sumber dana permanen yang digunakan perusahaan untuk operasionalnya yang akan memaksimalkan nilai perusahaan itu sendiri. Pencarian struktur modal yang optimal merupakan pekerjaan yang sangat sulit, karena adanya konflik yang mengarah kepada biaya agensi. Konflik lama terjadi antara pemegang saham dan pemegang obligasi dalam penetapan struktur modal optimal suatu perusahaan. Maka untuk mengurangi kemungkinan manajemen menanggung risiko berlebihan atas nama pemegang saham, perlu memasukkan beberapa batasan protektif. Struktur modal atau Debt to Equity Ratio (DER) merupakan rasio yang di gunakan untuk mengukur total utang yang digunakan terhadap total modal perusahaan. DER diatas satu bisa dikatakan DER bermasalah atau tidak sehat.

Mardiansyah (2012) dalam penelitiannya yang berjudul pengaruh profitabilitas dan operating leverage terhadap struktur modal, menyimpulkan bahwa profitabilitas berpengaruh negatif dan signifikan terhadap struktur modal, sedangkan operating leverage berpengaruh negatif namun tidak signifikan terhadap struktur modal. Hal ini berarti bahwa semakin besar laba perusahaan maka struktur modal perusahaan tersebut akan menurun. Dengan kenyataan ini perusahaan lebih menggunakan modal sendiri berupa laba ditahan karena laba perusahaan sangat berpengaruh pada struktur modal, karena sepanjang tahun penelitian perusahaan lebih mengunakan modal sendiri.

Penelitian ini memiliki hasil yang berbeda dengan apa yang dikemukakan Mardiansyah (2012), yang menyatakan bahwa profitabilitas berpengaruh negatif dan signifikan terhadap struktur modal. Putra dan Kesuma (2012) dalam penelitian mengenai pengaruh profitabilitas, likuiditas dan ukuran pertumbuhan terhadap struktur modal perusahaan, mengungkapkan bahwa profitabilitas dan likuiditas berpengaruh negatif dan signifikan terhadap struktur modal, ukuran perusahaan tidak memiliki pengaruh terhadap struktur modal, sedangkan tingkat pertumbuhan berpengaruh positif dan signifikan terhadap struktur modal. Dari penelitian ini hasil yang diperoleh untuk variabel profitabilitas memiliki kesamaan terhadap penelitian Mardiansyah (2012).

Menurut hasil dari penelitian Anita dan Sembiring (2016) dalam penelitiannya yang berjudul Analisis Pengaruh Profitabilitas, Pertumbuhan Aset, Risiko Bisnis, Tingkat Likuiditas dan Ukuran perusahaan terhadap Struktur Modal Perusahaan Jasa (sektor hotel, restoran dan pariwisata) yang terdaftar di BEI, menyimpulkan bahwa dari hasil analisis secara parsial diperoleh bawa variabel profitabilitas berpengaruh positif signifikan terhadap struktur modal. Variabel pertumbuhan aset berpengaruh positif dan signifikan terhadap struktur modal. Variabel risiko bisnis berpengaruh positif signifikan terhadap struktur modal. Variabel tingkat 


\section{Deni Sunaryo}

likuiditas berpengaruh positif signifikan terhadap struktur modal. Variabel ukuran perusahaan berpengaruh positif signifikan terhadap struktur modal.

Dari ulasan penelitian diatas bahwa banyak penelitian yang telah menganalisis berbagai pengaruh faktor internal terhadap struktur modal, akan tetapi hasil dari penelitian tersebut belum menunjukkan hasil yang konsisten. Berdasarkan penelitian tersebut, maka peneliti bertujuan untuk memperoleh bukti empiris mengenai "Pengaruh Profitabilitas Dan Struktur Aktiva Terhadap Struktur Modal Pada Perusahaan Manufaktur Sub Sektor Transportasi Di Asia Tenggara Tahun 2012-2018”.

\section{Landasan Teori dan Pengembangan Hipotesis}

\section{Struktur Modal}

Menurut Brigham dan Houtson dalam jurnal Batubara dkk (2017:3), kebijakan struktur modal melibatkan adanya suatu pertukaran antara risiko dan pengembalian.Struktur modal atau DER merupakan rasio yang di gunakan untuk mengukur total utang yang digunakan terhadap total modal perusahaan. Menurut Riyanto dalam jurnal Santoso dan Priantinah (2016:4) rumus menghitung DER yaitu:

$$
D E R=\frac{\text { total utang }}{\text { total ekuitas }}
$$

\section{Profitabilitas}

Profitabilitas adalah kemampuan menghasilkan laba. Profitabilitas bertujuan agar suatu perusahaan memperoleh laba atau kemampuan yang semaksimal mungkin. Menurut $\mathrm{S}$ Munawir dalam jurnal Eviani (2015:195), menjelaskan pengertian profitabilitas atau rentabilitas adalah kemampuan perusahaan untuk menghasilkan laba selama periode tertentu.Dalam analis rasio, kemampuan menghasilakan laba dapat dikaitkan dengan penjualan, aset atau modal. Menurut Setia dalam jurnal Santoso dan Piantinah (2016:4) untuk menghitung Profitabilitas yaitu dengan rumus:

$$
R O A=\frac{\text { laba bersih }}{\text { total asset }}
$$

\section{Struktur Aktiva}

Struktur aktiva adalah perimbangan atau perbandingan antara akiva tetap dan total aktiva Weston dan Bringham dalam jurnal Eviani (2015:195). Aktiva tetap (fixed assets) adalah aktiva yang secar fisik dapat dilihat keberadaannya dan sifatnya relatif permanen serta memiliki masa kegunaan (useful life) yang panjang. Aktiva tetap merupakan aktiva yang berwujud (tangble assets). Menurut Syamsuddin dalam jurnal Batubara dkk (2017:4) untuk menghitung aktiva tetap yaitu denga rumus:

$$
\text { fixed Assets }=\frac{\text { aktiva tetap }}{\text { total asset }}
$$




\section{Kerangka Pemikiran}

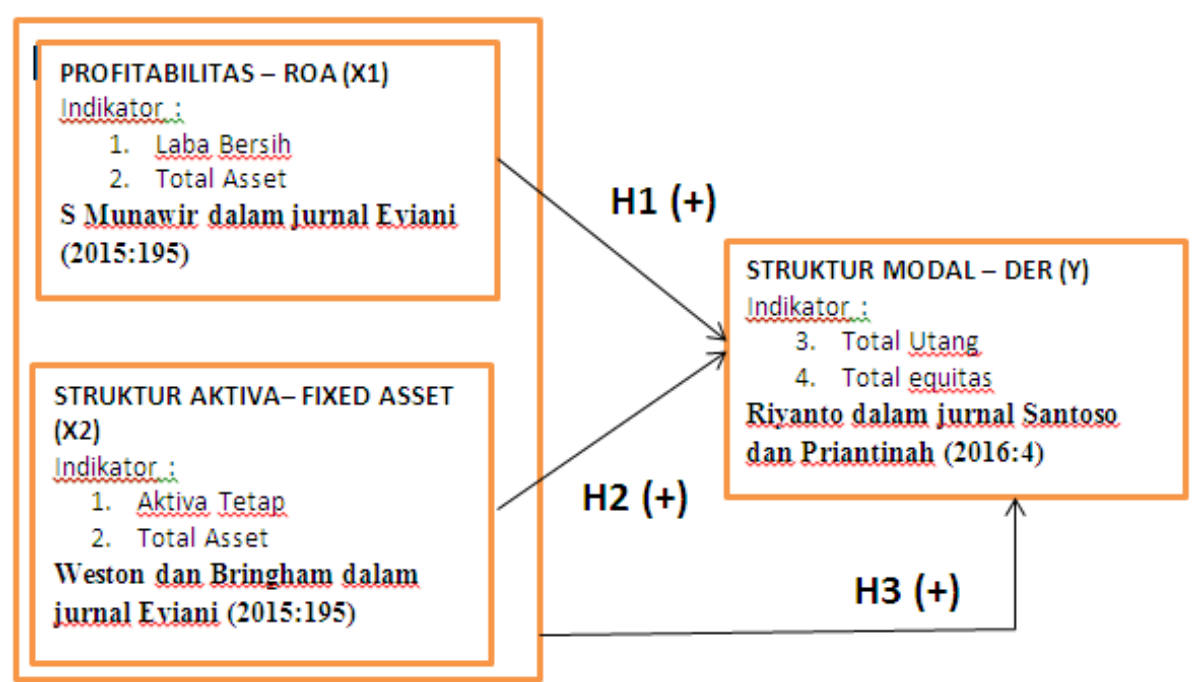

Gambar 1. Kerangka Pemikiran

\section{Pengaruh Profitabilitas Terhadap Struktur Modal}

Suatu perusahaan menggunakan profitabilitas untuk menghasilkan laba sebasar-besar mungkin. Apabila tingkat keuntungan profitabilitasnya menunjukkan tingkat yang tinggi dan struktur modal yang optimal maka bisa dikatakan perusahaan akan mengalami keuntungan yang tinggi. Apabila tingkat profitabilitasnya rendah perusahaan akan menolak menggunakan hutang untuk membiayai operasionalnya dan apabila tingkat profitabilitasnya yang tinggi maka perusahaan akan menambah penggunaan hutan. Bagi para investor hal ini menjadi acuan dalam memilih berinvestasi. Jika laba suatu perusahaan kurang baik maka pihak investor bisa mengambil keputusan untuk berivestasi atau tidak.

Berdasarkan teori dan hasil penemuan tersebut maka hipotesis pertama yang diajukan sebagai berikut. Menurut Wiwik Widyaningsing, Edi Budi Santoso, \& Hartono (2017):

H1 : terdapat pengaruh positif dan signifikan dimensi profitabilitas terhadap struktur modal.

\section{Pengaruh Struktur Aktiva Terhadap Struktur Modal}

Kebanyakan perusahaan industri sebagian besar lebih memilih modalnya tertanam dalam aktiva tetap (fixed assets), untuk mengutamakan pemenuhan modalnya dari modal yang permanen, yaitu modal sendiri dan sedangkan hutang sifatnya hanya pelengkap. Bisa dikatakan besarnya suatu modal sendiri harus bisa menutupi junlaj aktiva tetap dan jumlah aktiva yang lainnya yang sifatnya permanen. Pada perusahaan yang sebagian besar aktiva terdiri dari aktiva lancar akan mengutamakan kebutuhan dananya dengan utang jangka pendek.

Berdasarkan teori dan hasil penemuan tersebut maka hipoteis kedua yang diajukan sebagai berikut. Menurut I Putu Andre Sucita Wijaya \& I Made Karya Utama (2014):

$\mathrm{H} 2$ : terdapat pengaruh positif dimensi struktur aktiva terhadap struktur modal. 


\section{Deni Sunaryo}

\section{Pengaruh Profitabilitas Dan Struktur Aktiva terhadap Struktur Modal}

Dalam, hal ini bisa dikatakan bahwa profitabilitas dan struktur aktiva sangatlah berpengaruh terhadap struktur modal. Suatu perusahaan membutuhkan keuntungan laba yang sangat besar dan aktiva yang tetap tidak mudah menyusut. Suatu perusahaan akan dikatakan untung jika sebisa mungkin menghasilkan laba yang besar dengan utang yang sekecil-kecilnya.

Berdasarkan teori dan hasil penemuan tersebut maka hipotesis ketiga yang diajukan sebagai berikut. Sesuai dengan penelitian terdahulu dari Batubara dkk (2017):

H3 : terjadi pengaruh secara parsial profitabilitas dan struktur aktiva terhadap struktur modal.

\section{Metode Penelitian}

Menurut Sugiyono (2013:24), metode penelitian pada dasarnya merupakan cara yang ilmiah untuk mendapatkan data dengan tujuan dan kegunaan tertentu. Dalam melakukan penelitian, tentunya diperlukan suatu metode yang sesuai dengan tujuan penelitian yang hendak dicapai.

Metode yang digunakan dalam penelitian ini adalah metode kuantitatif. Menurut Sugiyono (2013:35) metode kuantitatif dapat diartikan sebagai metode penelitian yang berlandaskan pada filsafat positivisme, digunakan untuk meneliti pada populasi atau sampel tertentu, pengumpulan data menggunakan instrumen penelitian, analisis data bersifat kuantitatif/statistik dengan tujuan untuk menguji hipotesis yang telah ditetapkan.

Maka populasi dalam penelitian ini adalah laporan keuangan dari 8 perusahaan sub sektor transportasi yang terdaftar di Bursa Efek Asia Tenggara pada periode 2012-2018.

Tabel 1

Klasifikasi Perusahaan Sampel

\begin{tabular}{|c|c|c|c|}
\hline No & Kode & Nama Emiten & $\begin{array}{c}\text { Jenis } \\
\text { Perusahaan }\end{array}$ \\
\hline 1 & GIAA & PT. Garuda Indonesia & Transportasi \\
\hline 2 & BIRD & PT. Bluebird Group Indonesia & Transportasi \\
\hline 3 & CASS & PT. Cardig Aero Services Tbk Indonesia & Transportasi \\
\hline 4 & TSC & TASCO NYK Group Company Malaysia & Transportasi \\
\hline 5 & WPRTS & WESTPORTS Malaysia & Transportasi \\
\hline 6 & POSH & $\begin{array}{c}\text { Pacc Offshore Services Holdings LTD } \\
\text { Singapura }\end{array}$ & Transportasi \\
\hline 7 & ASIMAR & $\begin{array}{c}\text { Asian Marine Services Public Company } \\
\text { Limited Thailand }\end{array}$ & Transportasi \\
\hline 8 & AVV & $\begin{array}{c}\text { Asia Aviation Public Company Limited } \\
\text { Thailand }\end{array}$ & Transportasi \\
\hline
\end{tabular}




\section{Deni Sunaryo}

\section{Hasil Penelitian dan Pembahasan}

\section{Analisis Deskriptif}

Tabel 2

Statistik Deskriptif

Descriptive Statistics

\begin{tabular}{|c|c|c|c|c|c|c|c|c|c|}
\hline & $\bar{N}$ & Range & Minimum & Maximum & Sum & \multicolumn{2}{|c|}{ Mean } & Std. Deviation & Variance \\
\hline & Statistic & Statistic & Statistic & Statistic & Statistic & Statistic & Std. Error & Statistic & Statistic \\
\hline ROA & 56 & 84.10 & .10 & 84.20 & 536.46 & 9.5796 & 1.58168 & 11.83617 & 140.095 \\
\hline$F A$ & 56 & 64.99 & 27.09 & 92.08 & 3848.81 & 68.7288 & 2.23776 & 16.74584 & 280.423 \\
\hline DER & 56 & 2.99 & .17 & 3.16 & 58.47 & 1.0441 & .09087 & 67999 & .462 \\
\hline Valid N (listwise) & 56 & & & & & & & & \\
\hline
\end{tabular}

Sumber: IBM SPSS versi 23

Tabel 2 diatas menunjukkan bahwa jumlah pengamatan pada perusahaan manufaktur sub sektor transportasi dalam penelitian ini sebanyak tujuh periode.Berdasarkan perolehan data diketahui bahwa nilai minimum struktur modal (DER) 0,17 pada perusahaan Asian Marine Services Public Company Limited Thailand pada tahun 2015, nilai maksimum sebesar 3.16 pada perusahaan PT. Bluebird Group Indonesia pada tahun 2013, dan rata-rata $\quad 58.47$ dengan nilai standar deviasi sebesar .67999. Return On Assets (ROA) diperoleh dengan nlai minimum 0,10 pada perusahaan Asia Aviation Public Company Limited Thailand pada tahun 2018, nilai maksimum 84.20 pada perusahaan Asia Aviation Public Company Limited Thailand pada tahun 2012, dan rata-rata 536.46 dengan nilai standar deviasi sebesar 11.83617. Fixed Assets diperoleh dengan nilai minimum 27.09 pada perusahaan PT. Cardig Aero Services Tbk Indonesia pada tahun 2015, nilai maksimum 92.08 pada perusahaan PT. Bluebird Group Indonesia pada tahun 2015, dan rata-rata 3848.81 dengan nilai standar deviasi sebesar 16.74584 .

\section{Uji Asumsi Klasik}

\section{Uji Normalitas}

Tabel 3

Hasil Uji Normalitas

One-Sample Kolmogorov-Smirnov Test

\begin{tabular}{|ll|r|}
\hline & & $\begin{array}{r}\text { Unstandardiz } \\
\text { ed Residual }\end{array}$ \\
\hline N & & 56 \\
& Mermal Parameters & a,b \\
Most Extreme Differences & Std. Deviation & .0000000 \\
& Absolute & .60033720 \\
& Positive & .098 \\
& Negative & .098 \\
Test Statistic & & -.091 \\
Asymp. Sig. (2-tailed) & & .098 \\
\hline
\end{tabular}

a. Test distribution is Normal.

b. Calculated from data.

c. Lilliefors Significance Correction.

d. This is a lower bound of the true significance.

Sumber: IBM SPSS versi 23 
Hasil uji normalitas terpenuhi, mengacu pada hasil uji Kolmogorov yang nilai asymp sig 2 tailed nya lebih besar dari $0,05(0,200>0,05)$

\section{Uji Multikolinieritas}

\section{Tabel 4}

Hasil Uji Multikolinieritas

Coefficients $^{\mathrm{a}}$

\begin{tabular}{|c|c|c|c|c|c|c|c|c|}
\hline \multirow[b]{2}{*}{ Mode } & & \multicolumn{2}{|c|}{ Unstandardized Coefficients } & \multirow{2}{*}{$\begin{array}{c}\text { Standardized } \\
\text { Coefficients } \\
\text { Beta }\end{array}$} & \multirow[b]{2}{*}{$t$} & \multirow[b]{2}{*}{ Sig. } & \multicolumn{2}{|c|}{ Collinearity Statistics } \\
\hline & & $B$ & Std. Error & & & & Tolerance & VIF \\
\hline \multirow[t]{3}{*}{1} & (Constant) & 3.489 & 1.227 & & 2.843 & .006 & & \\
\hline & Ln_ROA & -.158 & .058 & -.343 & -2.715 & .009 & .955 & 1.047 \\
\hline & Ln_FA & -.810 & .286 & -.357 & -2.829 & .007 & .955 & 1.047 \\
\hline
\end{tabular}

a. Dependent Variable: Ln_DER

Sumber: IBM SPSS versi 23

Uji multikolinearitas terpenuhi karena setiap variabel memiliki nilai tolerance lebih besar $>0,10$ dan nilai VIF yang di bawah $<10$

\section{Uji Autokorelasi}

\section{Tabel 5}

\section{Hasil Uji Autokorelasi}

Model Summary

\begin{tabular}{|l|c|r|r|r|r|}
\hline Model & $\mathrm{R}$ & R Square & $\begin{array}{c}\text { Adjusted R } \\
\text { Square }\end{array}$ & $\begin{array}{l}\text { Std. Error of } \\
\text { the Estimate }\end{array}$ & $\begin{array}{c}\text { Durbin- } \\
\text { Watson }\end{array}$ \\
\hline 1 & $.385^{\mathrm{a}}$ & .148 & .115 & .44904 & 1.608 \\
\hline
\end{tabular}

a. Predictors: (Constant), lag_FA, lag_ROA

b. Dependent Variable: lag_DER

Sumber: IBM SPSS versi 23

Hasil uji auto korelasi menunjukkan nilai durbin watson (DW) sebesar 1,608 yang menunjukkan bahwa nilai DW berada di antara dl $(1,49541)$ sampai du $(1,64295)$. Nilai DW tersebut berada pada daerah hasil yang tidak bisa ditentukan ada atau tidaknya masalah autokorelasi positif atau negatif. Jadi penelitian tetap dapat dilanjutkan.

\section{Uji Heteroskedastisitas}

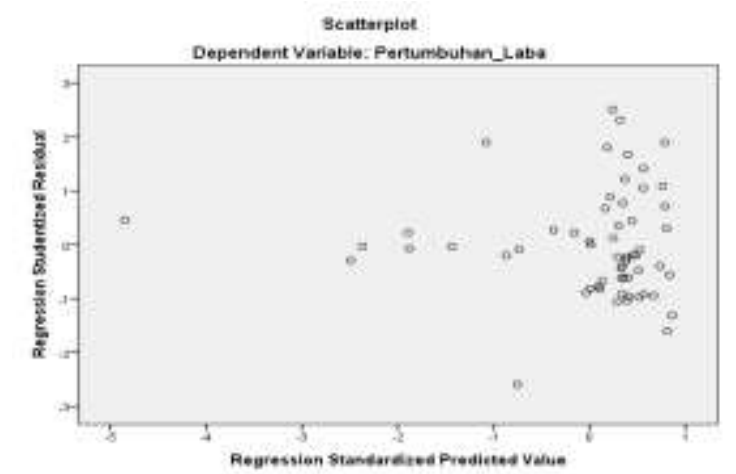

Sumber: IBM SPSS versi 23

Gambar 2. Hasil Uji Heterokedastisitas 


\section{Deni Sunaryo}

Hasil uji heteroskedastisitas menunjukkan bahwa data sudah menyebar dibawah dan diatas angka nol dan tidak membentuk pola.

\section{Analisis Data}

\section{Analisis Regresi Berganda}

\section{Tabel 6}

Hasil Analisis Regresi Berganda

Coefficients $^{a}$

\begin{tabular}{|c|c|c|c|c|c|c|}
\hline \multirow[b]{2}{*}{ Mod } & & \multicolumn{2}{|c|}{ Unstandardized Coefficients } & \multirow{2}{*}{$\begin{array}{c}\begin{array}{c}\text { Standardized } \\
\text { Coefficients }\end{array} \\
\text { Beta }\end{array}$} & \multirow[b]{2}{*}{ t } & \multirow[b]{2}{*}{ Sig. } \\
\hline & & $B$ & Std. Error & & & \\
\hline \multirow[t]{3}{*}{1} & (Constant) & 3.489 & 1.227 & & 2.843 & .006 \\
\hline & Ln_ROA & -.158 & .058 & -.343 & -2.715 & .009 \\
\hline & Ln_FA & -.810 & .286 & -.357 & -2.829 & .007 \\
\hline
\end{tabular}

a. Dependent Variable: Ln_DER

Sumber: IBM SPSS versi 23

Regresi berganda menggunakan data pada kolom unstandardize coefficient $\mathrm{B}$ hasil $\mathrm{t}$ (kolom t) menunjukkan bahwa nilai t hitung lebih besar dari t tabel pada hipotesis 1 dan 2 $(2,715 / 2,829>2,00575)$ dan nilai signifikansinya lebih kecil dari $0,05(0,009 / 0,007<0,05)$. Artinya hipotesis 1 dan 2 diterima/didukung.

Dari hasil-hasil analisis regresi tersebut maka dapat dibentuk suatu model estimasi sebagai berikut:

$$
\text { DER }=3,489-0,158 \text { ROA }-0,810 \text { FA }
$$

Persamaan regresi tersebut dapat dijelaskan sebagai berikut:

1. Koefisien konstanta menunjukkan nilai sebesar 3,489 artinya ROA dan Total Asset nilainya sama dengan nol, maka tingkat atau besarnya DER nilainya sebesar 3,489

2. Koefisien pada ROA (X1) menunjukkan nilai sebesar -0,158 yang artinya jika ROA meningkat 1 , maka DER akan mengalami penurunan sebesar 0,158

3. Koefisien Total Asset (X2) menunjukkan nilai sebesar -0,810 yang artinya jika Total Asset meningkat 1, maka DER akan mengalami penurunan sebesar 0,810.

\section{Uji Hipotsis \\ Uji Parsial (Uji t)}

Tabel 7

Hasil Uji Parsial (Uji t)

\begin{tabular}{|c|c|c|c|c|c|c|}
\hline & & \multicolumn{5}{|c|}{ Coefficients $^{a}$} \\
\hline \multirow{2}{*}{\multicolumn{2}{|c|}{ Model }} & \multicolumn{2}{|c|}{ Unstandardized Coefficients } & \multirow{2}{*}{$\begin{array}{c}\begin{array}{c}\text { Standardized } \\
\text { Coefficients }\end{array} \\
\text { Beta }\end{array}$} & \multirow[b]{2}{*}{$\mathrm{t}$} & \multirow[b]{2}{*}{ Sig. } \\
\hline & & $B$ & Std. Error & & & \\
\hline \multirow[t]{3}{*}{1} & (Constant) & 3.489 & 1.227 & & 2.843 & .006 \\
\hline & Ln_ROA & -.158 & .058 & -.343 & -2.715 & .009 \\
\hline & Ln_FA & -.810 & .286 & -.357 & -2.829 & .007 \\
\hline
\end{tabular}

a. Dependent Variable: Ln_DER

Sumber: IBM SPSS versi 23 


\section{Deni Sunaryo}

Berdasarkan tabel 4.6 diatas dapat diuraikan sebagai berikut:

- $\quad$ Nilai $t_{\text {hitung }}<\mathrm{t}_{\text {tabel }}(2,715>2,00575)$ dan signifikan $>0,05(0,009<0,05)$ maka Ho ditolak dan Ha diterima. Jadi dapat disimpulkan bahwa ROA secara parsial berpengaruh terhadap DER.

- Nilai $t_{\text {hitung }}<t_{\text {tabel }}(2,829>2,00575)$ dan signifikan $>0,05(0,007<0.05)$ maka Ho ditolak dan Ha diterima. Jadi dapat disimpulkan bahwa Total Asset secara parsial berpengaruh terhadap DER.

\section{Uji Simultan (Uji f)}

Tabel 8

Hasil Uji Simultan (Uji f)

ANOVA $^{\text {a }}$

\begin{tabular}{|rl|r|r|r|r|l|}
\hline \multicolumn{2}{|l|}{ Model } & \multicolumn{1}{c|}{$\begin{array}{c}\text { Sum of } \\
\text { Squares }\end{array}$} & df & Mean Square & F & Sig. \\
\hline 1 & Regression & 4.749 & 2 & 2.374 & 6.348 & $.003^{\mathrm{b}}$ \\
& Residual & 19.822 & 53 & .374 & & \\
& Total & 24.571 & 55 & & & \\
\hline
\end{tabular}

a. Dependent Variable: Ln_DER

b. Predictors: (Constant), Ln_FA, Ln_ROA

Sumber: IBM SPSS versi 23

Hasil uji $\mathrm{F}$ menunjukkan bahwa nilai $\mathrm{F}$ hitung lebih besar dari nilai $\mathrm{F}$ tabel yaitu 6,348 $>3,17$, dan nilai signifikansinya yang lebih kecil dari pada $0,05(0,003<0,05)$. Artinya semua variabel $\mathrm{X}$ berpengaruh secara simultan terhadap variabel $\mathrm{Y}$.

\section{Uji Koefisien determinasi $\left(\mathbf{R}^{2}\right)$}

\section{Tabel 9}

Hasil Uji Koefisien determinasi $\left(\mathbf{R}^{2}\right)$

Model Summary

\begin{tabular}{|l|l|r|r|r|}
\hline Model & R & R Square & $\begin{array}{c}\text { Adjusted R } \\
\text { Square }\end{array}$ & $\begin{array}{c}\text { Std. Error of } \\
\text { the Estimate }\end{array}$ \\
\hline 1 & $.440^{\mathrm{a}}$ & .193 & .163 & .61156 \\
\hline
\end{tabular}

a. Predictors: (Constant), Ln_FA, Ln_ROA

b. Dependent Variable: Ln_DER

Sumber: IBM SPSS versi 23

Nilai R2 menunjukkan bahwa variabel Y dipengaruhi oleh seluruh variabel X sebesar 19,3\%, sisanya80,7\% dipengaruhi oleh variabel lain diluar penelitian ini.

\section{Pembahasan Hasil Analisis Data (Pembuktian Hipotesis)}

\section{Pengaruh Profitabilitas Terhadap Struktur Modal}

Berdasarkan hasil perhitungan SPSS versi 23 diperoleh $t_{\text {hitung }}$ sebesar 2,715 dengan nilai signifikansi $0.009>0.05$ dan berdasarkan tabel distribusi $t$ diperoleh $t_{\text {tabel }}$ sebesar 2,00575 dan $t_{\text {hitung }} 2,715>2,00575$ maka $\mathrm{H}_{1}$ diterima, jadi dapat dijelaskan bahwa Profitabilitas $\left(\mathrm{X}_{1}\right)$ secara 


\section{Deni Sunaryo}

parsial berpengaruh terhadap Struktur Modal (Y).Hasil penelitian ini didukung oleh penelitian sebelumnya yang dilakukan oleh Wicaksono (2017) yang menyatakan bahwa hasil penelitian secara parsial menunjukkan bahwa variable profitabilitas berpengaruh signifikan terhadap struktur modal pada perusahaan makanan dan minuman yang terdaftar di BEI periode 20122016.Hasil penelitian serupa juga diungkap oleh Marfuah dan Nurlaela (2017), yang menyatakan bahwa terdapat pengaruh signifikan antara profitabilitas terhadap struktur modal pada perusahaan cosmetics and house hold di bursa efek Indonesia.

\section{Pengaruh Struktur Aktiva Terhadap Struktur Modal}

Berdasarkan hasil perhitungan SPSS versi 23 diperoleh $t_{\text {hitung }}$ sebesar 2,829 dengan nilai signifikansi $0.007>0.05$ dan berdasarkan tabel distribusi $t$ diperoleh $t_{\text {tabel }}$ sebesar 2,00575 dan $t_{\text {hitung }} 2,829>2,00575$ maka $\mathrm{H}_{2}$ diterima, jadi dapat dijelaskan bahwa Struktur Aktiva $\left(\mathrm{X}_{2}\right)$ secara parsial berpengaruh terhadap Struktur Modal (Y). Hasil penelitian sebelumnya yang dilakukan oleh Batubara dkk (2017) menyatakan bahwa struktur aktiva berpengaruh secara parsial terhadap struktur modal pada perusahaan makanan dan minuman yang terdaftar di Bursa Efek Indonesia Tahun 2012-2015. Hasil penelitian ini tidak mendukung hasil penelitian dari Eviani (2015) yang menyatakan bahwa struktur aktiva tidak memiliki pengaruh signifikan terhadap sruktur modal dikarenakan struktur aktiva pada perusahaan manufaktur tidak mengalami kenaikan yang signifikan selama periode 2011-2013. Hal ini menyebabkan manajemen tidak terlalu memperhatikan struktur aktiva dalam membuat kebijakan hutang baru.

\section{Pengaruh Profitabilitas dan Struktur Aktiva Terhadap Struktur Modal}

Berdasarkan hasil perhitungan SPSS versi 23 diperoleh uji F menunjukkan bahwa nilai $\mathrm{F}$ hitung lebih besar dari nilai $\mathrm{F}$ tabel yaitu $6,348>3,17$, dan nilai signifikansinya yang lebih kecil dari pada $0,05(0,003<0,05)$. Artinya semua variabel $\mathrm{X}$ berpengaruh secara simultan terhadap variabel Y. Hasil penelitian sebelumnya yang dilakukan oleh Riski Batubara, dkk (2017) menyatakan bahwa variabel-variabel bebas yaitu struktur aktiva (X1), ukuran perusahaan (X2), dan profitabilitas (X3) secara simultan berpengaruh signifikan terhadap struktur modal (Y).

\section{Kesimpulan}

Berdasarkan hasil analisis data dan pembahasan yang telah diuraikan pada bab sebelumnya, maka kesimpulan yang dapat diambil dari penelitian ini adalah sebagai berikut:

1. Berdasarkan hasil uji t variabel profitabilitas dengan tingkat signifikansi $0.009<0.05$, jadi secara parsial variabel profitabilitas berpengaruh negatif signifikan terhadap struktur modal pada perusahaan sub sektor transportasi yang terdaftar di Bursa Efek Asia Tenggara Periode 2012-2018.

2. Berdasarkan hasil uji t variabel struktur aktiva dengan tingkat signifikansi $0.007<0.05$, jadi secara parsial variabel struktur aktiva berpengaruh negatif signifikan terhadap struktur modal pada perusahaan sub sektor transportasi yang terdaftar di Bursa Efek Asia Tenggara Periode 2012-2018. 


\section{Deni Sunaryo}

3. Berdasarkan hasil uji $\mathrm{F}$ menunjukkan bahwa nilai $\mathrm{F}$ hitung lebih besar dari nilai $\mathrm{F}$ tabel yaitu $6,348>3,17$, dan nilai signifikansinya yang lebih kecil dari pada $0,05(0,003<0,05)$. Artinya semua variabel $\mathrm{X}$ berpengaruh secara simultan terhadap variabel $\mathrm{Y}$.

\section{Saran}

Dari hasil penelitian yang telah dilakukan, terdapat beberapa saran yang akan diberikan diantaranya sebagai berikut:

1. Bagi Perusahaan

Berdasarkan penelitian diatas bahwa variabel profitabilitas (X1) dan struktur aktiva (X2) berpengaruh secara negatif terhadap struktur modal (Y). Perusahaan harus meningkatkan nilai ROA dan FA agar nilai DER kurang dari 1,00 dan tidak terjadi kenaikan nilai DER.

2. Bagi Investor

Bagi investor diharapkan memperhatikan veriabel profitabilitas dan struktur aktiva. Dengan profitabilitas dan struktur aktiva yang tinggi maka semakin baik pula stuktur modal perusahaan.

3. Bagi Peneliti Selanjutnya

Untuk peneliti selanjutnya diharapkan untuk menambah variabel bebas yang lainnnya seperti, ukuran perusahaan, Likuiditas, Growth Opportunnity dan menambah jumlah periode sehingga mendapatkan informasi yang berbeda tentang pengaruh terhadap struktur modal perusahaan.

\section{Daftar Rujukan}

\section{Sumber Jurnal dan Buku:}

Anita, D., \& Sembiring, G. A. (2016). "Analisis Pengaruh Profitabilitas, Pertumbuhan Aset, Risiko Bisnis, Tingkat Likuditas dan Ukuran Perusahaan terhadap Struktur Modal Perusahaan Jasa (Sektor Hotel, Restoran dan Pariwisata) yang Terdaftar di Bursa Efek Indonesia Periode 2010-2014". Procuratio: Jurnal Ilmiah Manajemen, 4(4), 415-433.

Benkraiem, R., \& Gurau, C. (2013). "How do corporate characteristics affect capital structure decisions of French SMEs?". International Journal of Entrepreneurial Behavior \& Research.

Dewi, A. S. (2013). "Pengaruh Struktur Modal, Profitabilitas dan Ukuran Perusahaan Pada Nilai Perusahaan". E-Jurnal Akuntansi Universitas Udayana. Vol. 04. No. (02).

Eviani, A. D. (2016). "Pengaruh Struktur Aktiva, Pertumbuhan Penjualan, Dividend Payout Ratio, Likuiditas dan Profitabilitas terhadap Struktur Modal". Jurnal Akuntansi dan Sistem Teknologi Informasi, 11(2).

Ghozali, Imam. 2012. "Aplikasi Analisis Multivariate dengan Program IBM SPSS". Yogyakarta: Universitas Diponegoro

Ghozali, Imam. (2013). "Aplikasi Analisis Multivariate dengan Program IBM SPSS 21 Update PLS Regresi". Semarang: Badan Penerbit Universitas Diponegoro.

Ghozali, Imam. (2016). "Aplikasi Analisis Multivariete Dengan Program IBM SPSS 23 (Edisi

8)". Cetakan ke VIII. Semarang : Badan Penerbit Universitas Diponegoro

Kasmir. (2014). Analisis Laporan Keuangan, Edisi Pertama, Cetakan Ketujuh. J akarta:PT. Rajagrafindo Persada. 


\section{Deni Sunaryo}

Mallisa, M., \& Kusuma, H. (2017). "Capital structure determinants and firms' performance: empirical evidence from Thailand, Indonesia and Malaysia". Polish Journal of Management Studies, 16.

Mardiansyah, T. (2012). "Pengaruh Profitabilitas dan Operating Leverage terhadap Struktur Modal Perusahaaan Makanan dan Minuman yang terdaftar di Bursa Efek Indonesia". Jurnal Ekonomi. Universitas Negeri Padang.

Owolabi, S. A., \& Inyang, U. E. (2013). "International pragmatic review and assessment of capital structure determinants". Kuwait Chapter of Arabian Journal of Business and Management Review, 33(855), 1-14.

Pasaribu, M. Y., \& Sulasmiyati, S. (2016). Pengaruh Struktur Modal, Struktur Kepemilikan Dan Profitabilitas Terhadap Nilai Perusahaan Pada Perusahaan Sektor Industri Dasar Dan Kimia Yang Terdaftar Di Bei Tahun 2011-2014. Jurnal administrasi bisnis, 35(1), 154-164.

Pratiwi Batubara, R. A., dkk. (2017). Pengaruh Struktur Aktiva, Ukuran Perusahaan, dan Profitabilitas terhadap Struktur Modal (Studi pada Perusahaan Makanan dan Minuman yang Terdaftar di Bursa Efek Indonesia Tahun 2012-2015). Jurnal Administrasi Bisnis, 50(4), 1-9.

Putra, D. E., \& Kesuma, I. K. W. (2012). "Pengaruh Profitabilitas, Likuiditas, Ukuran Pertumbuhan terhadap Struktur Modal Industri Otomotif yang Terdaftar di Bursa Efek Indonesia". Jurnal Ekonomi. Bali: Universitas Udayana.

Rahmiati, R., \& Sari, W. (2013). "Pengaruh Capital Expenditure, Struktur Modal dan Profitabilitas terhadap Nilai Perusahaan (Studi pada Perusahaan Manufaktur yang Terdaftar di Bursa Efek Indonesia)". Jurnal Kajian Manajemen Bisnis, 2(1).

Marfuah, S. A., \& Nurlaela, S. (2017). Pengaruh Ukuran Perusahaan, Pertumbuhan Asset, Profitabilitas Dan Pertumbuhan Penjualan Terhadap Struktur Modal Perusahaan Cosmetics And Household Di Bursa Efek Indonesia. Jurnal Akuntansi dan Pajak, 18(01).

Santoso, Y., \& Priantinah, D. (2016). "Pengaruh Profitabilitas, Ukuran Perusahaan, Struktur Aktiva, Likuiditas dan Growth Opportunity terhadap Struktur Modal Perusahaan". Jurnal Profita: Kajian Ilmu Akuntansi, 4(4).

Sisilia Christil, F. T. (t.thn.). "PENGARUH STRUKTUR AKTIVA, UKURAN PERUSAHAAN DAN PROFITABILITAS TERHADAP STRUKTUR MODAL (STUDI KASUS PADA PERUSAHAAN PERTAMBANGAN YANG TERDAFTAR DI BURSA EFEK INDONESIA TAHUN 2010 2014)". e-Proceeding of Management : Vol.2, No.3 Desember 2015.

Sugiyono. (2014). "Metode Penelitian Pendidikan Pendekatan Kuantitatif, Kualitatif, dan R\&D". $\quad$ Bandung: Alfabeta.

Wahyuni, I., \& Ardini, L. (2017). "Pengaruh growth opportunity, profitabilitas dan kebijakan dividen terhadap struktur modal". Jurnal Ilmu dan Riset Akuntansi (JIRA), $6(4)$.

Wicaksono, D. A. (2017). "Pengaruh Prifitabilitas, Likuiditas dan Struktur Aktiva Terhadap Struktur Modal (Studi Pada Perusahaan Makanan dan Minuman Yang Terdaftar Di BEI Tahun 2012-2016)". Simki-Economic. Vol. 01. No. (03).

Wicaksono, I. P. (2014). "Pengaruh Profitabilitas, Struktur Aset dan Pertumbuhan Penjualan Terhadap Struktur Modal Serta Harga saham". E-Jurnal Akuntansi Universitas Udayana. Vol. 06. No. (03) .

Widyaningsih, W., Santoso, E. B., \& Hartono, H. (2017). PENGARUH STRUKTUR MODAL, KINERJA KEUANGAN, PROFITABILITAS DAN 
INOBIS: Jurnal Inovasi Bisnis dan Manajemen Indonesia

Volume 03, Nomor 04,September 2020

Deni Sunaryo

LIKUIDITAS TERHADAP NILAI PERUSAHAAN MANUFAKTUR DI BURSA EFEK INDONESIA (STUDI KASUS TAHUN 2012-2014). Journal Of Accounting, 3(3).

Wijaya, I. P. A. S., \& Sucita, P. A. I made Karya Utama. 2014. "Pengaruh Profitabilitas, Struktur Aset, dan Pertumbuhan Penjualan Terhadap Strukur Modal Serta Harga Saham". E-Jurnal Akuntansi Universitas Udayana. Hal, 514-530 